\title{
Temperature-Dependent Development, Life Table Parameters and Predation Rate of Euseius scutalis (A.- H.) Fed on the Two-Spotted Spider Mite
}

\author{
M. A. Osman ${ }^{*}$; G. M. Abou-Elella ${ }^{* *}$ and Alyaa A. Tawfik ${ }^{* * *}$ \\ *Agric. Zool. Dept., Fac. of Agric., Mansoura Univ., Mansoura, Egypt \\ **Pests and Plant Protec. Dept., Nat. Res. Center, Dokki, Cairo, Egypt \\ ***Plant Protec. Res. Inst., Agric. Res. Cent., Dokki, Cairo, Egypt
}

\begin{abstract}
Biological aspects, thermal requirement, predation rate and life table parameters of the phytoseiid predatory mite Euseius scutalis (A.- H.) fed on nymphs of Tetranychus urticae Koch was determined at four temperature degrees, $15,20,25$ and $30{ }^{\circ} \mathrm{C}$. The total developmental durations of female was correlated negatively with increasing temperature. Minimum developmental thresholds $\left(\mathrm{T}_{\mathrm{o}}\right)$ of egg, larva, protonymph, deutonymph, total immature stages and life cycle of $E$. scutalis female averaged, 4.26, 10.98, 6.90, 1.20, 2.49 and 2.89; respectively. On the other hand E. scutalis female required 208.33 DD to reach adulthood. The net rate of natural increase $\left(\mathrm{r}_{\mathrm{m}}\right)$ was $0.008,0.126$, 0.166 and 0.193 , whereas the finite rate of increase $\left(\mathrm{e}^{\mathrm{rm}}\right)$ averaged $1.092,1.134,1.181$ and 1.213 at $15,20,25$ and $30{ }^{\circ} \mathrm{C}$; respectively.
\end{abstract}

Key Words: Euseius scutalis, Tetranychus urticae, Biology, Life table, Thermal requirement, Predation rate.

\section{INTRODUCTION}

Mites of the family phytoseiidae are cosmopolitan and important natural enemies of several phytophagous mite pests on various agricultural crops. The phytoseiid mite Euseius scutalis (A.-H.) was firstly recorded in Algeria as Typhlodromus scutalis by Athias-Henriot (1958). It was reported as a widespread phytoseiid mite in Middle East countries and North Africa on a variety of host plants (Bounfour \& McMurtury, 1987 and Momen \& Abdel-Khalek 2008). In Egypt, it is considered one of the most predominant and widely distributed phytoseiid mite (Zaher, 1986 and ElLaithy \&Fouly, 1992). It is a facultative predator, which is not only mite predator but also feed on other preys and food nutrients such as whiteflies and pollens (Abdel halim et al., 2000 and Osman, 2000). However, on the basis of the classification of McMurtry and Croft (1997) and Croft et al., (2004), E. scutalis is a specialized pollen feeder and generalist predator which is belonging to the type IV life style.

Although, numerous studies on the influence of temperature on development and reproduction of phytoseiid species have been reported, yet no information has been cited about thermal requirements of E. scutalis. The present work aims to study the influence of temperature on it's biology, life table and predation rate. The thermal requirements and thresholds of $E$. scutalis when fed on T. urticae at four temperatures as a prerequisite to develop a better prediction of the predator populations will be studied.

\section{MATERIALS AND METHODS}

\section{Influence of different temperatures on} development of $E$. scutalis:

Leaf discs of $R$. communis, one square inch each, were used as a substrate for rearing the predator. Newly deposited eggs were singly transferred to leaf discs placed on wet cotton pads in Petri dishes (15 $\mathrm{cm}$ in diameter).

Predatory eggs of E. scutalis were separated into four major groups according to the tested temperature degrees $\left(15,20,25\right.$ and $\left.30 \pm 1{ }^{\circ} \mathrm{C}\right)$ and $70 \pm 5 \%$ R.H. All groups were provided daily with nymphs of $T$. urticae as prey.

\section{Statistical analysis:}

Data were analyzed by one way analysis of variance (ANOVA), and the means were separated using Duncan's Multiple Range Test (CoHort Software, 2004). Durations of eggs, larvae, protonymphs, deutonymphs were used to calculate developmental rates (1/developmental time) according to Omkar and James (2004), which were regressed against temperature. The regression parameters and slopes were used to estimate the lower temperature threshold for development (To) and the thermal constant K, (Campbell et al., 1974).

Degree-Day requirements: Algorithms have been developed using a variety of non-linear functions that describe the temperature/growth rate relationship (Wagner et al., 1984), but for most species the linear approximation is acceptable (Taylor and James, 1993). 


\section{Life table analyses:}

Life table parameters were calculated using a BASIC computer program (Abou-Setta et al., 1986) for females reared on various tested temperature degrees. Constructing a life table, using rates of agespecific (Lx), and fecundity (Mx) for each age interval ( $\mathrm{x}$ ) was assessed. The following population growth parameters were determined: the mean generation time $(T)$, gross reproductive rate (GRR) $(=\Sigma \mathrm{Mx})$, the net reproductive increase $\left(R_{o}\right)$, the intrinsic rate of increase $\left(r_{m}\right)$, and the finite rate of increase $(\lambda)$. The doubling time $(D T)$, cohort generation time $\left(T_{c}\right)$, capacity of increase $\left(r_{c}\right)$ and annual rate of increase (ARI) were calculated according to Carey (1993). The life tables were prepared from data recorded daily on developmental time, sex ratio, number of deposited eggs, fraction of eggs reaching maturity, and the survival of females. Interval of one day was chosen as the age classes for constructing the life table.

\section{Predation rate:}

The daily consumption of all individuals, including males, females, and immatures, was used to calculate the age-stage specific consumption rate $\mathrm{c}_{\mathrm{xj}}$. This is the mean number of $T$. urticae consumed by individual $E$. scutalis in age $\mathrm{x}$ and stage $\mathrm{j}$. The age-specific predation rate $\left(\mathrm{k}_{\mathrm{x}}\right)$ is the mean number of $T$. urticae consumed by E. scutalis at age $\mathrm{x}$ and was calculated by the following formula proposed by Chi and Yang (2003):

$$
k_{x}=\frac{\sum_{j=1}^{\beta} s_{x j} c_{x j}}{\sum_{j=1}^{\beta} s_{x j}}
$$

According to Chi and Yang (2003), the net predation rate $\left(\mathrm{C}_{\mathrm{o}}\right)$ gives the mean number of prey consumed by an average individual predator during its entire life span, and is calculated as:

$$
C_{0}=\sum_{x=0}^{\infty} k_{x} l_{x}
$$

The transformation rate from prey population to predator offspring $\left(Q_{p}\right)$ is the ratio of the net predation rate to the net reproductive rate (Chi and Yang, 2003). It is calculated as:

$$
\mathrm{Q}_{\mathrm{p}}=\mathrm{C}_{\mathrm{o}} / \mathrm{R}_{\mathrm{o}}
$$

Predation rate data were analyzed using the computer program CONSUME-MSChart as designed by Chi (2005).

\section{RESULTS AND DISCUSSION}

\section{Influence of different temperatures on development of $\boldsymbol{E}$. scutalis:}

Table (1) showed that eggs of E. scutalis hatched after 5. 10 days at $15{ }^{\circ} \mathrm{C}$; while 20,25 and $30{ }^{\circ} \mathrm{C}$ clearly accelerated hatching to $3.00,2.31$ and 2.00 days, respectively. Increasing temperature significantly shortened the developmental periods. Total immatures and life cycle averaged 11.50 \& $16.50 ; 10.12 \& 13.12$ and $7.06 \& 9.37$ days for female when reared at 15,20 and $25^{\circ} \mathrm{C}$, respectively. Total immatures and life cycle averaged 5.68 and 7.68 days when reared at $30{ }^{\circ} \mathrm{C}$.

\section{Influence of different temperatures on adult longevity and female fecundity of $\boldsymbol{E}$. scutalis:}

The pre-oviposition period of average E. scutalis female was $6.56,5.56,3.37$ and 2.81 days; while the female laid an average of 13.12, 18.75, 29.68 and 35.68 eggs at $15,20,25$ and $30{ }^{\circ} \mathrm{C}$, respectively (Tables $2 \& 3$ ). Sex ratio was $0.65,0.72,0.64$ and 0.76 at the same temperatures. Adult female lived for $44.06,38.18,30.68$ and 27.25 days; while, its lifespan averaged $60.56,51.12,40.06$ and 34.93 days at $15,20,25$ and $30{ }^{\circ} \mathrm{C}$, respectively.

El-Laithy and Fouly (1992) found that E. scutalis adult female longevity durated 27.12 days, when reared on T. urticae at $25^{\circ} \mathrm{C}$. In 2010 Osman et al., stated that adult female longevity and life span of $E$. scutalis reared on immatures of T. urticae at $28{ }^{\circ} \mathrm{C}$ were 17.66 and 23.93 days, respectively; while, $\mathrm{Al}$ - Shammery in the same year recorded that these periods averaged 26.4 and 34.42 days, when reared on immatures of $T$. urticae at $26^{\circ} \mathrm{C}$. The differences in findings regarding total developmental times may be due to differences in prey quality, local populations, and experimental conditions.

\section{Degree-Day Requirements:}

The relationship between temperature and rate of development in insects and mites is usually calculated as linear, but it is actually curvilinear (Sharpe and De Michele, 1977).

Minimum developmental thresholds $\left(\mathrm{T}_{\mathrm{o}}\right)$ of egg, larva, protonymph, deutonymph, immatures and life cycle of $E$. scutalis female were 4.26, 10.98, 6.90, $1.20,2.49$ and 2.89, respectively; when fed on nymphs of T. urticae. Whereas, E. scutalis female required 208.33 DD to complete development from egg to adult when reared on nymphal stages of T. urticae (Table 3 \& Fig. 1).

Lower thermal threshold for development and 


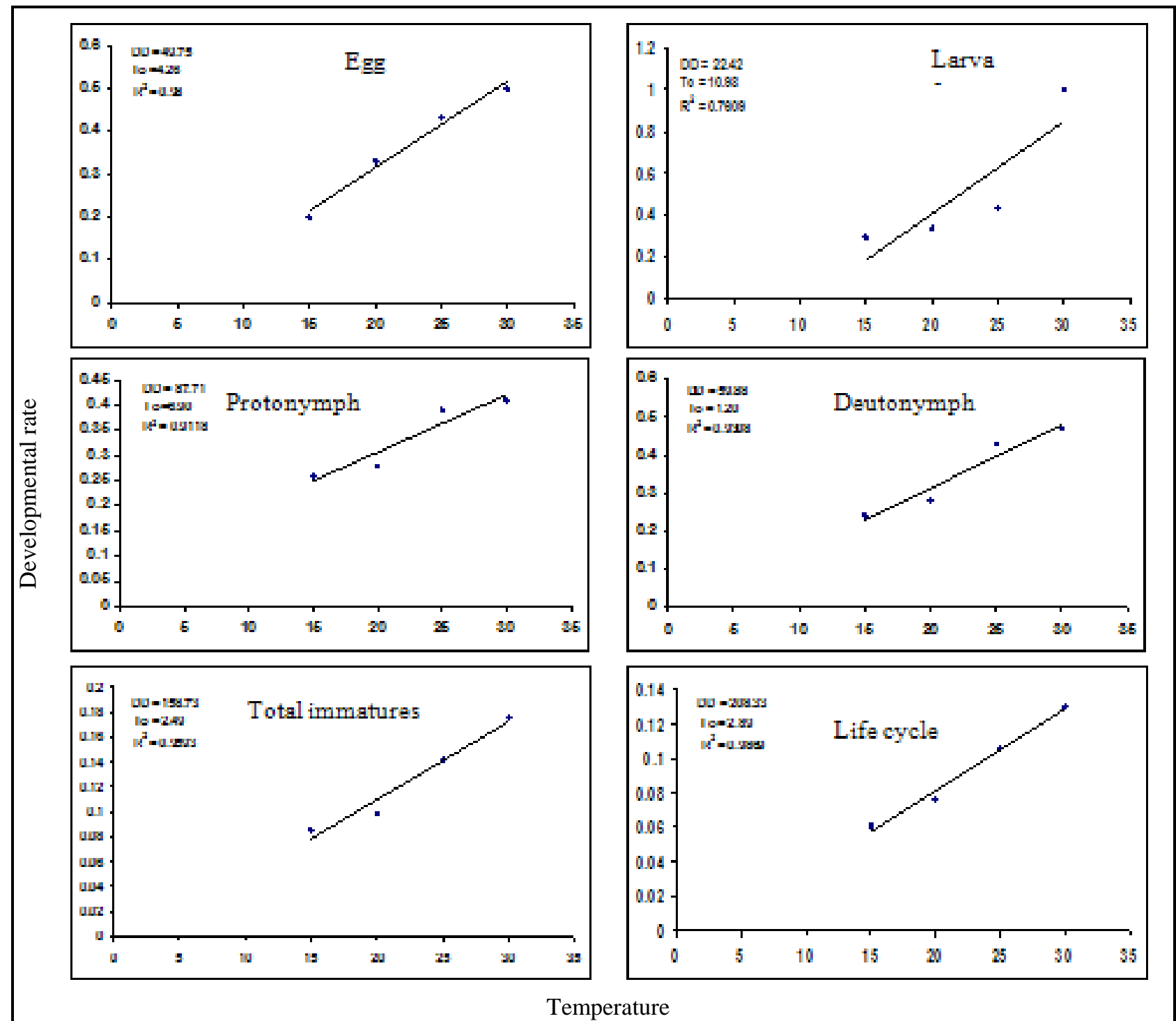

Fig.(1). Linear regression analysis of temperature versus developmental rate, degree-days requirements, and minimum developmental thresholds of $E$. scutalis female reared on nymphs of $T$. urticae

Table (1): Duration in days of developmental stages of Euseius scutalis fed on nymphs of Tetranychus urticae at different temperatures

\begin{tabular}{lcccccc}
\hline Temp. & Egg & Larva & Protonymph & Deutonymph & Total immatures & Life cycle \\
\hline 15 & $5.10 \pm 0.13_{a}$ & $3.33 \pm 0.12_{a}$ & $3.80 \pm 0.12_{a}$ & $4.12 \pm 0.12_{a}$ & $11.50 \pm 0.22_{a}$ & $16.5 \pm 0.22_{a}$ \\
\hline 20 & $3.00 \pm 0.15_{b}$ & $3.10 \pm 0.09_{b}$ & $3.46 \pm 0.12_{a}$ & $3.56 \pm 0.12_{b}$ & $10.12 \pm 0.42_{b}$ & $13.12 \pm 0.39_{b}$ \\
\hline 25 & $2.31 \pm 0.11_{c}$ & $2.31 \pm 0.11_{c}$ & $2.56 \pm 0.12_{b}$ & $2.31 \pm 0.11_{c}$ & $7.06 \pm 0.19_{c}$ & $9.37 \pm 0.22_{c}$ \\
\hline 30 & $2 . .00 \pm 0.11_{d}$ & $1.00 \pm 0.00_{d}$ & $2.43 \pm 0.12_{b}$ & $2.12 \pm 0.08_{c}$ & $5.68 \pm 0.15_{d}$ & $7.68 \pm 0.15_{d}$ \\
\hline
\end{tabular}

Table (2): Duration in days of Euseius scutalis adult females fed on nymphs of Tetranychus urticae at different temperatures

\begin{tabular}{cccccc}
\hline Temp. & Preoviposition & Oviposition & Postoviposition & Longevity & Lifespan \\
\hline 15 & $6.56 \pm 0.12_{a}$ & $21.62 \pm 0.34_{a}$ & $15.93 \pm 0.24_{a}$ & $44.06 \pm 0.28_{a}$ & $60.56 \pm 0.30_{a}$ \\
\hline 20 & $5.56 \pm 0.12_{b}$ & $18.62 \pm 0.34_{b}$ & $14.00 \pm 0.27_{b}$ & $38.18 \pm 0.1_{b}$ & $51.12 \pm 0.31_{b}$ \\
\hline 25 & $3.37 \pm 0.125_{c}$ & $16.06 \pm 0.28_{c}$ & $11.25 \pm 0.37_{c}$ & $30.68 \pm 0.49_{c}$ & $40.06 \pm 0.56_{c}$ \\
\hline 30 & $2.81 \pm 0.10_{d}$ & $14.31 \pm 0.50_{d}$ & $10.12 \pm 0.30_{d}$ & $27.25 \pm 0.61_{d}$ & $34.93 \pm 0.60_{d}$ \\
\hline
\end{tabular}

Means in each column having different letters are significantly different $(\mathrm{P}<0.05)$. 
Table (3). Linear regression analysis of temperature versus developmental rate, degree-days requirements, and minimum developmental thresholds of E. scutalis female reared on nymphys of $T$. urticae

\begin{tabular}{lcccc}
\hline \multicolumn{1}{c}{ Stage } & Regression & $\mathrm{R}^{2}$ & $\mathrm{~K}(\mathrm{DD})$ & $\mathrm{T}_{\mathrm{o}}$ \\
\hline Egg & $\mathrm{Y}=-0.0858+0.0201 \mathrm{x}$ & 0.980 & 49.75 & 4.26 \\
\hline Larva & $\mathrm{Y}=-0.4898+0.0446 \mathrm{x}$ & 0.760 & 22.42 & 10.98 \\
\hline Protonymph & $\mathrm{Y}=-0.0787+0.0114 \mathrm{x}$ & 0.911 & 87.71 & 6.90 \\
\hline Deutonymph & $\mathrm{Y}=-0.0202+0.0167 \mathrm{x}$ & 0.930 & 59.88 & 1.20 \\
\hline Immatures & $\mathrm{Y}=-0.0157+0.0063 \mathrm{x}$ & 0.959 & 158.73 & 2.49 \\
\hline Life cycle & $\mathrm{Y}=-0.0139+0.0048 \mathrm{x}$ & 0.986 & 208.33 & 2.89 \\
\hline
\end{tabular}

Table (4): Effect of different temperatures on the life table parameters of Euseius scutalis

\begin{tabular}{ccccccccccc}
\hline Temp. ${ }^{\circ} \mathrm{C}$ & Mean Total Fecundity & $\mathrm{R}_{0}$ & $\mathrm{~T}$ & $\mathrm{r}_{\mathrm{m}}$ & $\mathrm{e}^{\mathrm{rm}}$ & $\mathrm{GRR}$ & $\mathrm{DT}$ & $\mathrm{T}_{\mathrm{c}}$ & $\mathrm{r}_{\mathrm{c}}$ & ARI \\
\hline 15 & $13.12 \pm 0.22$ & 8.019 & 23.63 & 0.008 & 1.092 & 8.021 & 7.830 & 24.83 & 0.083 & $1.074 \times 10^{14}$ \\
\hline 20 & $18.75 \pm 0.47$ & 12.690 & 20.13 & 0.126 & 1.134 & 12.694 & 5.471 & 22.20 & 0.144 & $1.211 \times 10^{20}$ \\
\hline 25 & $29.68 \pm 1.09$ & 14.318 & 15.97 & 0.166 & 1.181 & 20.360 & 4.15 & 17.25 & 0.154 & $2.98 \times 10^{26}$ \\
\hline 30 & $35.68 \pm 0.83$ & 15.880 & 14.30 & 0.193 & 1.213 & 23.420 & 3.570 & 15.85 & 0.174 & $5.98 \times 10^{30}$ \\
\hline
\end{tabular}

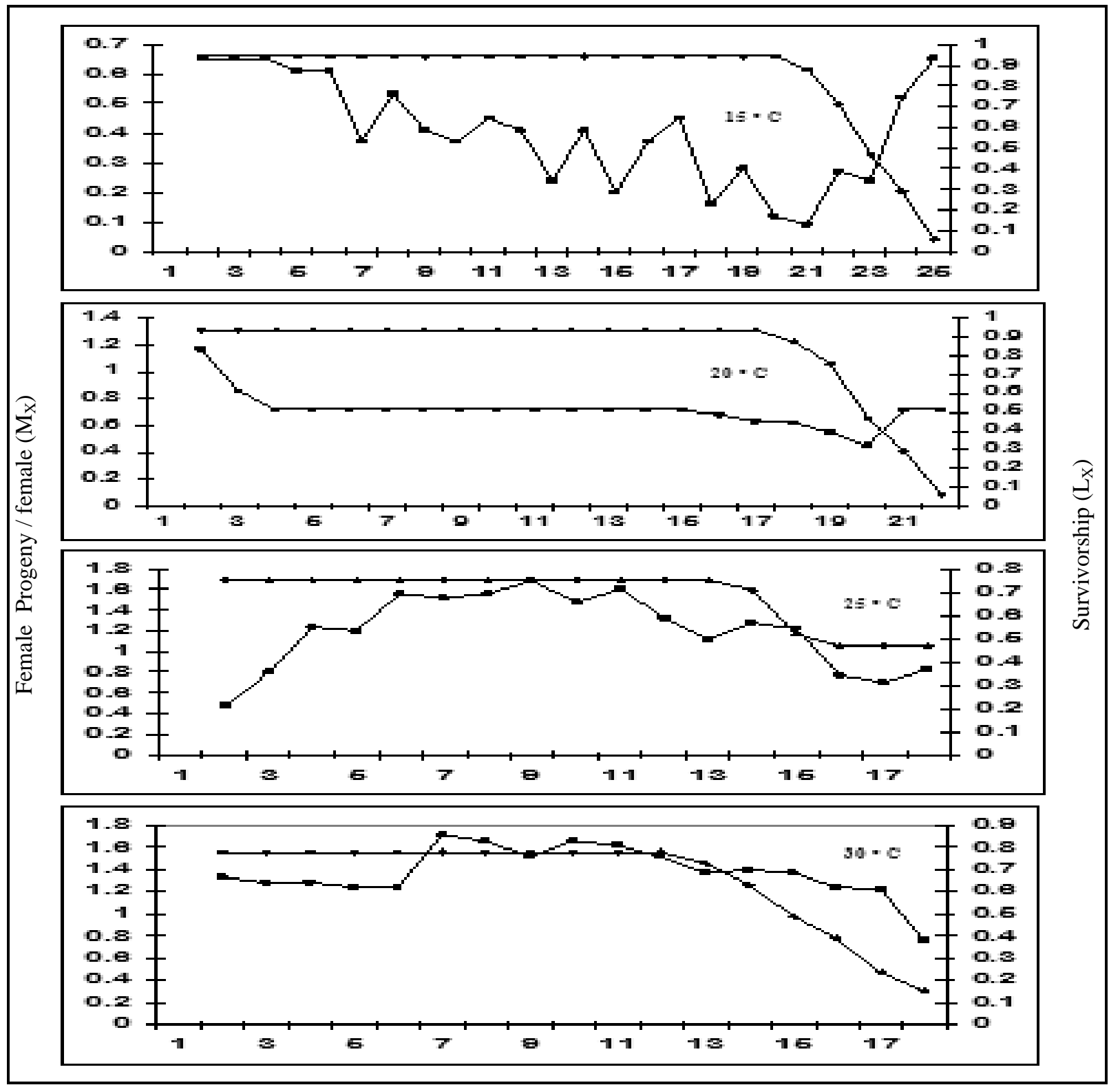

Fig.( 2 ): Age- specific fecundity $\left(\mathrm{M}_{\mathrm{x}}\right)$ and survivorship $\left(\mathrm{L}_{\mathrm{x}}\right)$ of Euseius scutalis fed on nymphal stages of $T$. urticae at four constant temperature degrees. 
thermal constant are useful indicators for an insect's potential distribution (Campbell et al., 1974). The results in this study showed that a threshold temperature of $2.89{ }^{\circ} \mathrm{C}$ and 208.33 accumulated day degrees were required for E. scutalis to complete one generation. Rencken and Pringle (1998) showed that $N$. californicus $\mathrm{T}_{\mathrm{o}}$ and $\mathrm{K}(\mathrm{DD})$ were 8.30 and 100.10 , respectively when reared on $T$. urticae. whereas, Gotoh et al. (2004) reported that $\mathrm{T}_{\mathrm{o}}$ and K(DD) for $N$. californicus was 10.90 and 59.20 when reared on T. urticae. Also, Rasmy et al.(2010) found that $\mathrm{T}_{\mathrm{o}}$ and $\mathrm{K}$ (DD) for P. plumifer was 13.22 and 126.58. For instance, El Taj and Jung (2012) stated that $\mathrm{T}_{\mathrm{o}}$ and $\mathrm{K}$ (DD) for $N$. californicus was 10.98 and 55.15 when fed on Panonychus ulmi. From previous results, E. scutalis had the lowest thermal constant and highest lower threshold suggesting that $E$. scutalis remained active at lower temperature and had a potential to develop over a wide range of temperatures.

\section{Life table parameters:}

The present study indicated that thermal factor has a great influence on life table parameters (Table 4).

The survival curves of E. scutalis fed on T. urticae under different temperatures followed a type I pattern in which most eggs developed to maturity and death occurred gradually over an extended ovipositional period (Fig. 2). These results agree with that of Fouly and El-Laithy (1992); Osman (2000); Osman, 2005 and Al-Shammery (2010).

The net reproductive rate $\left(\mathrm{R}_{0}\right)$ was significantly affected by temperature as $\left(\mathrm{R}_{0}\right)$ values averaged $8.019,12.690,14.318$ and 15.880 when E. scutalis was kept at $15,20,25$ and $30^{\circ} \mathrm{C}$, respectively. Also, the mean generation time $(\mathrm{T})$ averaged $23.63,20.13$, 15.97 and 14.30 when the predator individuals were kept at the same temperature. El-Laithy and Fouly (1992) found that $\mathrm{R}_{0}$ of E. scutalis and T. swirskii were 17.22 and 22.97 when reared on $T$. urticae. Osman (2000) showed that $\mathrm{R}_{0}$ and $\mathrm{T}$ of E. scutalis was 16.03 and 28.63, respectively when reared on $T$. urticae immatures at $25{ }^{\circ} \mathrm{C}$, while Ali and Zaher (2007) recorded that $\mathrm{R}_{0}$ and $\mathrm{T}$ of $T$. swirskii, when reared on immatures and eggs of $T$. urticae were 7.40, 25.92 and 6.92, 25.52, respectively. Also, AlShammery (2010) reported that $\mathrm{R}_{0}$ and $\mathrm{T}$ of $E$. scutalis were 26.373 and 14.88 when reared on $T$. urticae at $26^{\circ}$ C., whereas Osman et al.(2010) recorded it 16.84 and 12.28.

However, the intrinsic rate of natural increase $\left(r_{m}\right)$ is a key demographic parameter useful for predicting the population growth potential of an animal under given environmental conditions (Birch, 1948), because $r_{m}$ reflects an overall effect on development, reproduction and survival (Southwood and Henderson ,2000). Theoretically, a predator that has a population growth rate $\left(r_{m}\right)$ equal or greater than its prey could be able to regulate the population of the prey (Sabelis, 1992). The biotic potential $\left(\mathrm{r}_{\mathrm{m}}\right)$ of the main phytoseiid species constitutes $0.18-0.334$. Data in table (3) showed that $r_{m}$ values were $0.008,0.126,0.166$ and 0.193 individuales/ female/day when E. scutalis was reared at 15, 20, 25 and $30{ }^{\circ} \mathrm{C}$, respectively. McMurtry and Croft (1997) stated that the intrinsic rates of natural increase $\left(r_{m}\right)$ of generalist mite predators were sometimes below 0.1 but increased to 0.25 when fed on spider mites or pollen. For instance, Nomikou et al. (2001) showed that $\mathrm{r}_{\mathrm{m}}$ of E. scutalis fed on Panonychus citri averaged $0.23-0.29$ according to the temperature. Also, Kasap and Lu (2004) recorded that $\mathrm{r}_{\mathrm{m}}$ value of $E$. scutalis fed on P. citri was between 0.16 and 0.29 by increasing temperature; while Momen and El-sawi (2008) stated that $r_{m}$ value did not exceed 0.14 when the same predatory fed on eggs of cotton leaf worm. However, Al-Shammery (2010) and Osman et al. (2010) reported that $\mathrm{r}_{\mathrm{m}}$ value of E. scutalis was 0.220 and 0.229 when reared on T. urticae. Therefore, it can be concluded that the net rate of natural increase was highly influenced by thermal factor, as soon as $\mathrm{e}^{\mathrm{rm}}$ ranged between 1.092 and 1.213 at the same temperatures. On the other hand, the doubling time (DT) of E. scutalis was $7.830,5.471,4.150$ and 3.570 at 15, 20, 25 and $30{ }^{\circ} \mathrm{C}$. Also, gross reproductive rate (GRR) ranged between 8.021 and 23.420 at the same temperatures.

In the present study, the cohort generation time $\left(\mathrm{T}_{\mathrm{c}}\right)$ of E. scutalis was $24.83,22.20,17.25$ and 15.85 , at $15,20,25$ and $30{ }^{\circ} \mathrm{C}$; while capacity of increase $\left(r_{c}\right)$ ranged between 0.083 and 0.174 . Also, Annual Rate of Increase (ARI) ranged between $1.074 \times 10^{14}$ and $5.98 \times 10^{30}$ when E. scutalis was kept at the aforementioned temperatures, respectively. Hoque et al.(2008) reported that $\left(\mathrm{T}_{\mathrm{c}}\right)$ for $P$. persimilis was 10.754, 13.747 and 22.252 in summer, autumn and winter seasons, Also, $\left(r_{c}\right)$ was $0.1747,0.1715$ and 0.0960 in the same seasons. $\left(\mathrm{T}_{\mathrm{c}}\right)$ and $\left(r_{c}\right)$ of $T$. urticae were 13.057, 15.934 and 28.972 and $0.1676,0.1735$ and 0.0544 in summer, autumn and winter, respectively. Osman et al., (2010) recorded that the cohort generation time $\left(\mathrm{T}_{\mathrm{c}}\right)$, capacity of increase $\left(\mathrm{r}_{\mathrm{c}}\right)$ and annual rate of increase (ARI) of E. scutalis were $14.35,0.196$ and $2.39 \mathrm{x}$ $10^{36}$ when reared on T. urticae at $28^{\circ} \mathrm{C}$. Whereas, the net predation rate $\mathrm{C}_{\mathrm{o}}$ for $E$. scutalis at 15, 20, 25 
and $30{ }^{\circ} \mathrm{C}$ ranged between 47.84 and 124.64, nymphs, respectively.

\begin{tabular}{ccc}
\hline Temp. ${ }^{\circ} \mathrm{C}$ & $\mathrm{C}_{\mathrm{o}}$ & $\mathrm{Q}_{\mathrm{p}}$ \\
\hline 15 & 47.84 & 5.96 \\
20 & 112.97 & 8.90 \\
25 & 124.64 & 8.70 \\
30 & 100.68 & 6.34 \\
\hline
\end{tabular}

The net predation rate gives the mean number of prey consumed by an individual during its life span. It is a demographic parameter that represents the predation capacity of the predator population including all individuals of both sexes and those that died before the adult stage. The ratio of the net predation rate to the net reproductive rate gives the transformation rate from the prey population to predator offspring. This ratio is defined as $Q_{p}(C h i$ and Yang, 2003). The transformation rate from prey population to predator offspring $\mathrm{Q}_{\mathrm{p}}$ for $E$. scutalis fed on nymphs of $T$. urticae was 5.96, 8.90, 8.70 and 6.34 at same temperatures. This means that it needs 17.7 prey individuals for the reproduction of one predator egg. This $\mathrm{Q}_{\mathrm{p}}$ gives an demographic estimation for the relationship between the reproduction rate and predation rate of predator. Tommasini et al. (2004) reported that net predation rate of the four Orius species (O. laevigatus, $O$. majusculus, $O$. niger and $O$. insidiosus ) reared at $26{ }^{\circ} \mathrm{C}$ on Frankliniella occidentalis (Pergande) adults was 68.8, 62.9, 59.4 and 76.5, respectively. On other hand, Bailey et al. (2011) stated that the net predation rate Cybocephalus flavocapitis Smith was 1874 scales when reared on Aulacaspis yasumatsui Takagi.

As a result, it can be concluded that temperature has a considerable effect on the biology, life table, predation rate of E. scutalis when reared on $T$. urticae nymphs. Therefore, for an ecological and economical pest management program, the temperature should be integrated with the life tables of predator and prey to optimize the efficiency of biological control.

\section{REFERENCES}

Abdel halim, S. M.; Hanna, M. A.; Abdella, M. M. and Ramadan, M. F. 2000. Evaluation of food type, availability of food and competition as factors affecting mass rearing of the predaceous mite Euseius scutalis (A.-H.) (Acari: Phytoseiidae). Egyptian journal of biological pest control., 10 (1): 33-38.

Abou-Setta M.M. and Childers C.C. 1986. Life 48: a BASIC computer program to calculate life table parameters for an insect or mite species. Fla. Entomol.; 69(4): 690-697.

Ali, F. S. and Zaher, M. A. 2007. Effect of food and temperature on the biology of Typhlodrompis swirskii (Athias - Henriot) (Acari : Phytoseiidae). Acarines 1: $17-22$.

Al-Shammery, K. A. 2010. Different biological aspects of the predaceous mite Euseius scutalis (Acari: Gamasida: Phytoseiidae) and the effects due to feeding on three tetranychid mite species in Hail, Saudi Arabia. Asian Journal of Biological Sciences, $3: 77-84$.

Athias-Henriot, C. 1958. Contribution a la connaissance du genre Typhlodromus Scheuten. (Acariens Parasitiformes, Phytoseiidae). Description de deux espèces nouvelles d'Algerie et clé des espèces du groupe finlandicus -Rev. Patol. Veg. Entom. Agric. France, 37(2): 181-186

Bailey, R., Tai Chang, N and Lai, P. 2011. Two-sex life table and predation rate of Cybocephalus flavocapitis Smith (Coleoptera: Cybocephalidae) reared on Aulacaspis yasumatsui Takagi (Hemiptera: Diaspididae) in Taiwan. Journal of Asia-Pacific Entomology, 14: 433-439.

Birch, L. C. 1948.The intrinsic rate of natural increase of an insect population. J.Anim.Ecol., 17: $15-26$.

Bounfour, M. and McMurtry, J.A. 1987. Biology and ecology of Euseius scutalis (Athias-Henriot) (Acarina: Phytoseiidae). Hilgardia, 55: 1-23.

Campbell, A., B. Frazer, N. Gilbert, A. Guitierrez, and M. Mackauer. 1974. Temperature requirements of some aphids and their parasites. J. Appl. Ecol., 11: 431-438.

Carey, J. R. 1993. Applied demography for biologists with special emphasis on insects. Oxford University Press, New York.

Chi, H. 2005. TWOSEX-MSChart: a computer program for the age-stage, two-sex life table analysis. (http://140.120.197.173/Ecology /download/Twosex-MSChart.zip).

Chi, H. and Yang, T.C., 2003. Two-sex life table and predation rate of Propylaea japonica Thunberg (Coleoptera: Coccinellidae) fed on Myzus persicae (Sulzer) (Homoptera: Aphididae). Environ. Entomol., 32: 327-333.

CoHort Software. 2004. CoStat. www.cohort.com. Monterey, California, USA.

Croft, B.A.; Blackwood, J.S. and McMurtry, J.A. 2004. Classifying lifestyle types of phytoseiid mites: diagnostic traits. Exp. Appl. Acarol.,33: 247-260.

El- Laithy, A. Y. and Fouly, A. H. 1992. Life table parameters of the two phytoseiid predators Amblyseius scutalis (Athias-Henriot) and A. swirskii A.- H. (Acari, Phytoseiidae) in Egypt. J. 
Applied Entomol., $113:$ 8-12.

El Taj, H. F. and Jung, C. 2012. Effect of temperature on the life-history traits of Neoseiulus californicus (Acari: Phytoseiidae) fed on Panonychus ulmi. Exp. Appl. Acarol., 56:247-260.

Fouly, A. H. and El- Laithy, A. Y. 1992. Immature stages and life histrory of the predatory mite species Amblyseius barkeri (Hughes) (Acarina : Gamasida, Phytoseiidae). Deutsche Entomol., Zeitschrift, $39: 427-435$.

Gotoh, T.; Yamaguchi, K. and Mori, K. 2004. Effect of temperature on life history of the predatory mite Amblyseius (Neoseiulus) californicus (Acari: Phytoseiidae). Exp. \& Appl. Acarology, 32: $15-30$.

Hoque, M. F.;Islam, W. and Khalequzzaman, M. 2008. Life tables of two - spotted spider mite Tetranychus urticae koch (Acari: Tetranychidae) and its predator Phytoseiulus persimilis AthiasHenriot (Acari: Phytoseiidae). J. Bio. Sci., 16: 110.

Kasap, I. and Lu, E.E.2004. Life history of Euseius scutalis feeding on citrus red mite Panonychus citri at various temperatures. Bio. Control, 49: 645-654.

McMurtry, J. A. and Croft, B.A. 1997. Life styles of phytoseiid mites and their roles in biological control. Ann. Rev. Entomol.,42: 291-321.

Momen, F. M. and Abdel-Khalek, A. 2008. Influence of diet on biology and life-table parameters of the predacious mite Euseius scutalis (A.-H.) (Acari: Phytoseiidae). Acta Phytopathol. Entomol. Hungarica, 41 (6): 418430.

Momen, F. M. and El-Sawi, S. 2008. Life- history traits of the predaceous mites Euseius scutalis (A.-H.) (Acari: Phytoseiidae) on eggs of three insects (Lepidotera: Noctuidae). Acta Phytopathol. Entomol. Hungarica, 43: $163-170$.

Nomikou, M.; Janssen, A.; Schraag, R. and Sabelis, M. W. 2001. Phytoseiid predators as potential biological control agents for Bemicia tabaci. Exp. \& Appl. Acarol., 25: 271 - 291.

Omkar and James, B. E. 2004. Influence of prey species on immature survival, development, predation and reproduction of Coccinella transversalis Fabricius (Col., Coccinellidae). J. Appl. Entomol., 128: 150-157.

Osman, M. A., 2000. Feasibilty of using some predaceous mites in biological control. M. Sc. Thesis, Fac. Agric., Mansoura Univ., Egypt, 134pp.

Osman, M. A., 2005. Biological and ecological studies on certain predatory insects and mites associated with phytophagous mites and feasibilityof using it in biological control. Ph. D. Thesis, Fac. Agric., Mansoura Univ., Egypt, $211 \mathrm{pp}$.

Rasmy, A. H.; Osman, M. A. and Abou-Elella, G. M. 2010. Temperature influence on biology, thermal requirement and life table of the predatory mites Agistemus exsertus Gonzalez and Phytoseius plumifer (Can. \& Fanz.) reared on Tetranychus urticae Koch. Archieves of Phytopathology and Plant Protection, 44(1): 85 - 96.

Rencken, I.C. and Pringle, K.L 1998. Developmental biology of Amblyseius californicus (McGregor) (Acarina: Phytoseiidae), a predator of tetranychid mites, at three temperatures. African Entomology, 6(1): 41-45.

Sabelis, M. W. 1992. Predatory arthropods. In: M. J. Crawley (Ed.), Natural Enemies, the population biology of predators, parasites and diseases. Blackwell Scientific Publications, London, pp. 264

Sharpe, J. H. and De Michele, D. W. 1977. Reaction kinetics of poikilotherm development. J. Theor. Biol., 64: 649 - 670.

Southwood, T.R.E. and Henderson, P.A. 2000. Ecological methods. Third edition. Blackwell Sciences, Oxford, $524 \mathrm{pp}$.

Wagner, T. L., H. Wu, P.J.H. Sharpe, R.M. Schofield and Coulson, R.N. 1984. Modelling insect development rates: A literature review and application of biophysical model. Ann. Ent. Soc. Am. 77: 208 - 225.

Taylor, Ann and James, D. G. 1993. Effect of temperature on development and survival of Amblyseius victoriensis (Womersley) (Acari: Phytoseiidae). Internat. J. Acarol., 18(2):

Tommasini, M.G.; Vanlenteren, J.C. and Burgio, G.2004. Biological traits and predation capacity of four Orius species on two prey species. Bull. Insectology, 57:79-93.

Zaher, M. A. 1986. Survey and ecological studies on phytophagous, predacious and soil mites in Egypt. PL. 480 Programme USA. II- Predaceous \& Nonphytophagous mites (Nile Valley and Delta), pp 567. 